\title{
RESENHA
}

BETTO, F.; GLEISER, M. Conversa sobre a fé e a ciência: com Waldemar Falcão. Rio de Janeiro: Agir, 2011. 334 p. (ISBN 978-85-220-1129-2).

\section{UMA CONVERSA A CONSIDERAR NO ENSINO DE CIÊNCIAS?}

Ciência versus religião é tema que não se ausenta na literatura da área de ensino de ciências. Seja em relatos de pesquisa ou ensaios teóricos, sob diferentes referenciais ou linhas de pensamento, não são poucas as discussões que recaem sobre esse tema. Então, pode-se previamente imaginar que uma conversa sobre fé e ciência entre um religioso dominicano e um cientista agnóstico tenha influências formativas e ideias tão divergentes e consolidadas que, no mínimo, constitua-se em algo contraproducente, inútil e, portanto, não traga contribuições de relevo para o ensino de ciências. Isso seria realidade se não fossem os atores dessa conversa quem são e o tipo de diálogo ético travado entre ambos. Por certo, contra-producente e inútil não são adjetivos aplicáveis à Conversa sobre a fée a ciência entre Frei Betto e Marcelo Gleiser.

Transformada em livro, essa conversa mediada por Waldemar Falcão ocorreu no Rio de Janeiro, durante quatro dias, em meados de 2010. A conversa é inteligente e instigante, pois não são poucas as vezes que no seu percurso mobiliza o leitor, fazendo-o usar a memória para resgatar personagens, fatos históricos ou algumas situações apontadas em obras diversas da literatura, da cinematografia, das artes plásticas e, até mesmo, de histórias em quadrinhos. Personagens da ciência, como Descartes, Einstein, Fermi, Hawking, Galileu, Newton, Kepler e Plank, de modo pertinente na conversa de ambos, dividem espaço com persona- lidades diversas, como Marx, Paulo Freire, Jacques Maritain, Tristão de Athayde, Santo Agostinho, Santo Tomás de Aquino, Santa Teresa de Ávila, Dalai Lama, Isaac Asimov, Arthur Clarke, Lula e Obama. As menções sobre literatura (Drácula, de Bram Stoker; 1968 - o ano que não terminou, de Zuenir Ventura; $O$ pequeno príncipe, de Saint Exupéry; O livro que ninguém leu, de Owen Gingerich; Minority Report e Caçador de Androides - Blade Runner-, de Philip K. Dick; Frankenstein, de Mary Shelley; Contato, de Carl Sagan; 2001e 2010, de Arthur C. Clarke) também dividem espaço com menções a peças teatrais (Hair; O rei da vela), filmes (Batismo de Sangue, de Helvécio Ratton; Entrevista com o vampiro; 2001, uma odisseia no espaço, de Kubrick, Contato, de Zemeckis) e histórias em quadrinhos (Asterix; Abraracurcix). Quem proporciona isso à conversa, auxiliando para torná-la ainda mais agradável, são os dois protagonistas, que apresentam conhecimentos de áreas diversas das suas, conseguindo fazer interessantes conexões nos argumentos 
que constroem, sem cair em relativismos ou desordens nas ideias.

O conteúdo do livro mantém, na íntegra, um formato de diálogo que flui sem desgastes e cujo desenho estrutural perpassa os seguintes tópicos do sumário: "Apresentação" (p. 9-17); "Trajetórias" (p. 19-79); "Ciência e Fé” (p. 81 - 155); "O poder" (p. 157 - 257); "Até o Fim (do Mundo, do Universo) (p. 259 - 334)". No entanto, como se trata de uma conversa, não há um percurso unidirecional, pois um assunto puxa outro, e as conexões temáticas vão se formando também pela retomada de assuntos mencionados - às vezes, prévia e superficialmente - em momentos anteriores.

Os assuntos tratados são diversificados. Não necessariamente nesta ordem, e com graus distintos de aprofundamento, fazem parte da conversa o big bang, o poder e a hegemonia da religião e da ciência na linha histórica, conceito de vida, criação, clonagem, células-tronco, campo magnético da Terra, fenômenos paranormais e meditação. Em certo momento, também pós-modernidade e modernidade entram na discussão de forma sutil (como pano de fundo), quando Frei Betto e Marcelo Gleiser se posicionam sobre o avanço da ciência e as respectivas relações de felicidade e melhora de vida das pessoas.

Nas concordâncias ou discordâncias, o diálogo se mantém aberto, crítico e sem preconceitos. Nos argumentos difundidos por todo o texto acerca de diferentes questões, como foi citado em exemplos anteriores, ambos apresentam suas ideias utilizando as áreas que atuam, além de se manifestarem sobre outras áreas (filosofia, literatura, arte), que, afinal, no conjunto, constituem as diferentes formas como o ser humano constrói os seus conhecimentos.

Pode-se dizer que o diálogo entre Frei Betto e Marcelo Gleiser não se reduz a um conjunto de ideias que leve a uma mera classificação, ou seja, a uma determinação a respeito de ciência e religião, se são metodológica e epistemologicamente incompatíveis, complementares ou incomensuráveis. Ainda que isso possa ser feito pelo leitor, a síntese do diálogo extrapola tal categorização, ou seja, traz outras contribuições na maneira simples, mas balizada e crítica, com que os enunciadores falam de ciência e fé um para o outro: "No fundo, ambas, a fé e a ciência, estão servindo como um veículo de transcendência da condição humana, de ir além, de explorar uma dimensão desconhecida" (Marcelo Gleiser, p. 87); "De intenção, de intencionalidade, exato! E a ciência não lida com isso, é uma narrativa que explica como funciona o mundo, e não por que o mundo funciona" (Marcelo Gleiser, p. 98); "Pois é, mas a religião não pode ter a pretensão de expli-car o como" (Frei Betto, p. 99); "Há que se admitir que ciência e fé são duas visões do mundo. Melhor dizendo, duas mundividências. A ciência procura compreender a natureza desse mundo em que vivemos, como ele se originou, quais os seus elementos e as leis que o regem. Já a fé nos induz ao Transcendente, nos faz 'apalpar' o Mistério e concede-nos os óculos sobrenaturais que nos permitem compreender a relação de Deus conosco e com o Universo" (Frei Betto, p. 327); "Seria atestado de suprema ignorância negar o papel da ciência nas nossas vidas [...]. Não podemos ignorar 
também o papel da fé. Ela oferece uma outra ótica de encarar o mundo e a vida" (Frei Betto, p. 328); “Eu gosto de dizer que o ateísmo radical é logicamente inconsistente, [...] prefiro adotar a posição agnóstica: mesmo que não veja evidências para a existência de entidades sobrenaturais, não posso descartá-las a priori. Sabemos pouco sobre o mundo" (Marcelo Gleiser, p. 333).

As divergências de ideias, de posicionamentos sobre algumas questões polêmicas e os aspectos formativos de ambos não atrapalham a conversa. Pelo contrário, enriquecem as discussões de tal maneira que, às vezes, o leitor fica com a impressão de que também um debatedor está aprendendo com o outro.

Apesar de haver interessantes pontos convergentes, ambos expõem suas divergências em uma perspectiva que nos faz pensar na ética discursiva habermasiana. Habermas (1999) coloca a argumentação no lugar da ação teleológica, ou seja, por meio da linguagem, busca-se o consenso de uma forma livre de toda coação externa e interna. Nesse caso, a base da ética discursiva habermasiana está na autenticidade dos participantes, entendimento mútuo pela argumentação, simetria de participação e ausência de coação. Essa é uma colocação superficial e recortada da teoria de Habermas, mas serve como um indicativo de que "Conversa sobre a fé e a ciência" se dá numa dimensão da ética discursiva.

Quanto à mediação do diálogo, cumpre-se bem o seu papel. Ainda que algumas interferências dispensáveis tenham aparecido pelo meio do caminho, no geral, a condução é positiva.

Por fim, cabe dizer que o exposto nesta resenha é intencionalmente uma resposta afirmativa ao título questionador que escolhemos (Uma conversa a considerar no ensino de Ciências?). Conteúdo e forma, além da concordância ou não concordância com as ideias apresentadas na conversa, por si só, já abrem interessantes e diferentes possibilidades para o ensino de ciências (educação básica, licenciatura, formação continuada). No entanto, se a resposta de outros leitores for negativa, ainda assim, valerá a leitura.

\section{BIBLIOGRAFIA}

HABERMAS, J. Comentários à ética do discurso. Lisboa: Instituto Piaget, 1999.

Data de recebimento: 02/07/2011

Data de aprovação: 10/08/2011

Data da versão final: 20/12/2011 